\title{
Sing, Dance, and Be Merry: The Key to Successful Urban Development?
}

\author{
Youngwha Kee ${ }^{1}$, Yunji $\mathrm{Kim}^{2,3}$ \& Yoonjin Lee ${ }^{1}$ \\ ${ }^{1}$ Department of Lifelong Education, Soongsil University, Seoul, South Korea \\ ${ }^{2}$ Graduate School of Public Administration, Seoul National University, Seoul, South Korea \\ ${ }^{3}$ Department of City and Regional Planning, Cornell University, Ithaca, New York, USA \\ Correspondence: Yunji Kim, Department of City and Regional Planning, Cornell University, Ithaca, New York \\ 14850, USA. E-mail: yk634@cornell.edu
}

Received: January 26, 2014 Accepted: March 16, 2014 Online Published: April 29, 2014

doi:10.5539/ass.v10n9p245 URL: http://dx.doi.org/10.5539/ass.v10n9p245

\begin{abstract}
This study examines a unique case of urban redevelopment conflict in Seoul, South Korea. The Duriban case is one of the few urban redevelopment cases in South Korea that was peacefully resolved with protection of tenants' rights. The research aimed to answer why this case was peacefully resolved while other redevelopment cases have been contentious and even violent. Through documentary analysis and in-depth interviews with key actors, we identified the following eight categories as important factors: emotional support; sympathy; loose networks or bonds; continued action and volunteerism; place of interaction and bonding; encouragement and motivation for participation; transformation of physical space into a psychological space; and creating a meaningful and symbolic space. The findings highlight how community building through arts and cultural activities can be an important tool for socially just urban redevelopment.
\end{abstract}

Key words: urban development, urban conflict, community building, culture and art, civil protest

\section{Urban Development or Urban Conflict?}

Does urban development always lead to progress? Government officials and politicians have used this term to promise economic growth and a better future for local residents, but the term has also been linked to gentrification, forced evictions, violent conflicts, destruction of community, and injustice. Amidst the cases of unjust urban development cases around the world, the question of whether it is possible to achieve both development and social justice remains.

In South Korea (hereafter referred to as Korea), this seemed to be an impossible task as the words "urban development" came to symbolize something sinister after the Yongsan (Note 1) case: an urban redevelopment conflict that led to a large fire, twenty three injuries, and six deaths. (Note 2) Four years after the Yongsan fire, the land remains empty, offering a chilling visualization of the words "creative destruction": a dominant paradigm of redevelopment policies in the past. Although many argue that this paradigm has been replaced by a focus on rehabilitation, preservation, and adaptive reuse (Fainstein \& Fainstein, 2012), the idea seems to be very much alive in several areas (e.g. Rahman, 2001; Dobbs, 2002; Smart, 2002; Greene, 2003; Ha, 2004; Zhang 2004; Doshi, 2012). Korea has not been an exception (Kim, 2009).

However, in 2011, the case of Duriban unfolded with an unusual outcome: urban development with the triumph of tenants and community building. It began with the ordinary process of a private contractor purchasing a large plot of land, ordering immediate evacuation, and tenants organizing a desperate demonstration. However, the case ended with a peaceful negotiation in June 2011 and the tenants successfully relocated to a proximate location.

This study began with a simple question of why these seemingly similar cases have led to such dissimilar outcomes: one a tragedy and the other an inspirational story. (Note 3) The Duriban case can provide important insight for urban development processes so that they actually lead to the positive outcomes they promise, instead of a conflict ending in tragedy. Existing models of urban conflict and development have mostly been based on findings from the United States and Europe. The few studies of urban development that examine the cases of Hong Kong, Shanghai, and Tokyo (e.g. Dowall, 1994; Ng, 2002; Zhu, 2002; Waley, 2007; Wu, Xu \& Yeh, 2007; 
Yang \& Chang, 2007; He \& Wu, 2009; Sorenson, Okata \& Fujii, 2010) have pointed out that there are important differences between East Asian cases and that of the United States and Europe. Therefore, we expect the findings of this study to be useful not only for Korea, but also for other East Asian countries. Moreover, we expect the findings to have implications for states in the Western Hemisphere as well, since Korea has both uniquely Eastern characteristics as well as Western.

The outline of this paper is as follows. We begin our discussion with a short overview of the history of urban redevelopment in South Korea. Next, we introduce the methodology of this study in detail from case selection, data collection, to analysis. The results are presented and followed by a detailed discussion and interpretation of findings. Finally, we conclude with policy implications and suggestions for future studies in urban redevelopment and conflict.

\section{Urban Development in Korea}

Large scale urban redevelopment in Korea can be traced back to the late 1950s when Korea was beginning to recover from the devastating effects of the Japanese Occupation and the Korean War. Concerns over slums and deteriorating housing units in the capital city Seoul began to surface, but any attempts to fix these were carried out in sporadic actions.

Under the leadership of Park Chung Hee, urban development plans began to take shape with the 1962 City Planning Act. This Act outlined the details of urban planning with the stated purpose of promoting the public interest and enhancing quality of life, yet the practical driving forces behind the Act were the increased demands for urban housing due to urbanization. The Act was revised in 1971 to include a chapter on urban redevelopment plans dictating the requirements of any redevelopment projects. The amendment also allowed the Minister of Construction to choose development zones, which would be supported by the national government in the form of financial incentives and other resources for the developer(s). As with other policies during the Park Chung Hee era, the main focus was on economic development, progress, and growth. The issue of "clearing" or "cleaning" Seoul of slums or shantytowns was an integral part of this Act. A temporary measure on the improvement of housing units applicable from 1973 to 1981 declared housing unit improvements as an essential part of city planning, thereby providing a legal basis for governments to deal with unauthorized housing units.

In 1976, the chapters on urban redevelopment plans were separated from the City Planning Act to create the Urban Renewal Act. However, the redevelopment plans were less than successful in its implementation as the government lacked sufficient funds and lack of residents' support. In 1983, a new framework for urban development called Hapdong [joint] redevelopment was adopted. Under this framework, development projects were led by a commercial developer and an association comprised of property owners. The local government simply limited the maximum development density and the rest of the project was driven by market principles. While developers and property owners gave favorable reviews for this framework, the issue of relocation and socioeconomic inequalities remained (Lee, Lee \& Yim, 2003).

It was only in 1989 that concern for lower class residents formalized into a temporary measure. Even so, there was a large scale slum clearance movement right before the 1988 Olympic Games, and it was only in the 1990s that the "clean slate" model began to lose popularity as it seemed a clean slate was nowhere to be found in the densely populated Seoul. Instead, the idea of renewal, renovation, and preservation developments began to emerge.

In 2002, the City and Residential Environment Maintenance Act was legislated with a focus on terms for redevelopment plans of deteriorated areas. In particular, the Seoul Metropolitan Government initiated The New Town Project in 2002 with stated goals of promoting more equal development in Seoul, and especially narrowing the gap of housing quality between the Gangnam and Gangbuk districts. (Note 4) Already, criticisms against the New Town Project for its disregard of rule of law, social justice, and human rights have been voiced (Oh, 2006; Cho, 2010; Hong, 2010; Byun, 2011; Kim \& Jung, 2011; Yang, 2011). Even though the Korean redevelopment policies are incorporating more rhetoric of social justice and quality of life, the situation on the ground seems to be long-lasting echoes of the authoritarian regime with decision-making dominated by market principles, focus on property owners' rights, and frequent use of despotic power to push development plans forward (Kim, 2009).

Tenants' rights, in particular, are often at risk in Korean urban development. In Korea, when a business tenant moves out of a unit he or she receives a premium from the new tenant that is moving in. In other words, when a new tenant wishes to move into a unit he or she pays a deposit and rent to the owner, and in addition, a one-time premium to the previous tenant. The expectation is that when this tenant is moving out, he or she will receive the same amount or higher premium from the next tenant. However, in cases of urban redevelopment plans, where an entire building or buildings are purchased by a large corporation, the tenants are ordered to evacuate their 
units without the possibility of receiving this new tenant premium. Although the newly revised legislations provide for some monetary compensation of these evictions, the prices are inadequate for business owners to relocate to an area of similar market.

Despite the important role of governments in urban redevelopment, there is surprisingly little research done on this topic specifically from the perspective of the public sector. In particular, studies in Korean have mostly been approached from the economics and real estate field that look at costs or effects on the market (Choi, 2001; Lee, 2008; Kim, 2010; Lee, Bae \& Choi, 2011) or from legal perspectives that criticize the lack of legislative framework for redevelopment cases (Oh, J.G., 2006; Moon, 2009; Yeo, 2010; Lee, E.G., 2010; Lee, I.S., 2011; Lee, J.S., 2011; Oh, J.J., 2012;). There are few studies that have taken a comprehensive approach from the perspective of governments that are the leading actors in urban redevelopment processes. This study analyzes the Duriban case from a planning and policy perspective to provide insights and implications for the public sector.

\section{Case Background, Data, and Methodology}

\subsection{Case Background}

Case study is useful for answering questions of "how" or "why" in regards to a phenomenon or outcome by looking into its entire process (Yin, 2009). Stake (2005) recommends this method when a specific case can give new meaning and interpretation to a previously thought as general phenomenon. Duriban fits this profile since previous local development sites have been characterized as contentious and violent, but the Duriban case has been described as peaceful and even joyful.

The Duriban case was selected as an explanatory single-case study. We were initially attracted to this case as a counter example to the Yongsan case. In detail, the Yongsan case was publicized because of its high level of conflict that ended in an accident with six deaths and twenty three injured, and has come to act as a symbol of conflict and struggle. In contrast, the Duriban case has become publicized for its arts and cultural activities and is often cited for its creation or development of a new community.

Duriban was a restaurant located near the Hongik University area (also known as Hongdae area) in Mapo gu, Seoul, South Korea that served Kalguksu and Bossam. (Note 5) The name of the restaurant means a large round dining table. The restaurant was owned and managed by a novelist and his wife. They had invested everything they had into this restaurant with their savings of 87 million won (approximately 80 thousand USD) and a 25 million won (approximately 23 thousand USD) loan, that is a total of 112 million won (approximately 103 thousand USD). However, in less than two years this area was designated as a development zone by Seoul city government and the building was sold to a construction company with plans to build a new station for the airport subway line. They were offered 3 million won (approximately 2700 USD) for relocation costs and ordered to vacate the building immediately. When the couple refused to leave under these terms, the construction company hired private thugs who closed down the restaurant by force. The couple began their sit-down protest on 24 December 2009. As information about their situation began to spread by word of mouth and especially social networking services, others came to join the sit-down and the restaurant served as the location of a 531 days long sit-down protest until 7 June 2011.

During the protest, a wide variety of arts and cultural activities took place at Duriban. In the beginning, fellow writers of the owner's husband came to offer their support, and soon indie band musicians who used to perform near the Hongdae area showed up. These bands held small scale performances in the beginning that quickly gained a large audience and on May Day (May 1st), 2010, 62 bands came together to host a joint concert titled, "51+." The concert lasted for two days and had fifteen hours of nonstop music. A similar large scale concert took place on May Day, 2011 again. After the first May Day Concert success, a wide variety of culture and arts activities took place at Duriban on a regular basis. Table 1 is a description of the various activities that took place at Duriban 
Table 1. Detailed list of culture and arts activities at Duriban

\begin{tabular}{|c|c|c|c|}
\hline $\begin{array}{l}\text { Scheduled } \\
\text { frequency }\end{array}$ & Category & Title & Details \\
\hline $\begin{array}{l}\text { Every } \\
\text { Monday }\end{array}$ & Music & Sky Roof Concert & $\begin{array}{l}\text { - Period: } 11 \text { January } 2010 \text { - } 24 \text { June } 2011 \\
\text { - A couple called 'Uhm vocal, Kim player' supported } \\
\text { the protest via accordion and guitar performance } \\
\text { - The title Sky Roof Concert was chosen because the } \\
\text { performance takes place in the streets, so that regular } \\
\text { citizens can be part of the concert }\end{array}$ \\
\hline $\begin{array}{l}\text { Every } \\
\text { Tuesday }\end{array}$ & Movie & $\begin{array}{l}\text { Duriban } \\
\text { documentary } \\
\text { screening }\end{array}$ & $\begin{array}{l}\text { - Period: } 3 \text { September } 2010 \text { - } 28 \text { June } 2011 \\
\text { - Organized by Pooreun youngsang [Blue Films], a } \\
\text { documentary production group. } \\
\text { - Screened mostly independent films and social } \\
\text { commentary films }\end{array}$ \\
\hline $\begin{array}{l}\text { Every } \\
\text { Thursday }\end{array}$ & Religion & Candlelight services & $\begin{array}{l}\text { - Since March } 2010 \\
\text { - In the beginning was held every Thursday, but later } \\
\text { on they were held irregularly }\end{array}$ \\
\hline Every Friday & Music & Kalguksu Concerts & $\begin{array}{l}\text { - Period: } 12 \text { March } 2011 \text { - June } 2011 \\
\text { - Singers who have previous performance experience } \\
\text { at sit-in sites }\end{array}$ \\
\hline $\begin{array}{l}\text { Every } \\
\text { Saturday }\end{array}$ & Music & $\begin{array}{l}\text { Independence } \\
\text { Concert }\end{array}$ & $\begin{array}{l}\text { - Period: } 27 \text { February } 2010 \text { - } 11 \text { June } 2011 \\
\text { - } \quad \text { Approximately fifty concerts in total } \\
\text { - Voluntary participation of indie bands who perform } \\
\text { near Hongdae area } \\
\text { - Organized the } 51+\text { Concert and Independence Music } \\
\text { Producer Meeting on May Day } 2010 \text { and } 2011\end{array}$ \\
\hline Every Sunday & Humanities & $\begin{array}{l}\text { Humanities and } \\
\text { language courses }\end{array}$ & $\begin{array}{l}\text { - Period: November } 2010 \text { - April } 2011 \\
\text { - Humanities courses consist of introductory } \\
\text { philosophy and world history } \\
\text { - English courses were structured as English } \\
\text { gatherings with global solidarity as its purpose }\end{array}$ \\
\hline \multirow[t]{4}{*}{ Once a month } & \multirow[t]{4}{*}{ Literature } & \multirow[t]{4}{*}{ Literary forum } & $\begin{array}{l}\text { - Period: July } 2010 \text { - April } 2011 \\
\text { - Seven meetings total } \\
\text { - Organized by the Freedom Committee of the Korean } \\
\text { Writers Association } \\
\text { - Informal, invited one writer or poet to give a lecture } \\
\text { and then hold discussions }\end{array}$ \\
\hline & & & $\begin{array}{l}\text { - Period: November } 2010 \text { - June } 2011 \\
\text { - Organized by literature clubs } \\
\text { - Invited seven to eight poets and writers for poetry } \\
\text { readings }\end{array}$ \\
\hline & & & $\begin{array}{l}\text { - Audience participation } \\
\text { - Began as a protest against the Korea Electric Power } \\
\text { Corporation decision to cut electricity to Duriban at the } \\
\text { request of developers }\end{array}$ \\
\hline & & & $\begin{array}{l}\text { - Widely publicized through social networking } \\
\text { services }\end{array}$ \\
\hline
\end{tabular}




\subsection{Data and Methodology}

A preliminary assessment of the case indicated it would be difficult to create an accurate picture of this case through a strictly theoretical approach that fails to incorporate the real life details of this unique case. Therefore we used a mixed method for data collection to converge evidence for triangulation and utilized as many sources as possible.

In detail, we approached this case study through document analysis and in-depth interviews. (Note 6) Document data were collected in February 2011 through internet news, websites, and videos. Based on an elementary understanding of the case from a review of these documents, we conducted in-depth interviews from July through September 2011.

For document analysis, we collected 135 documents that directly deal with Duriban from the following sources: an online forum of Duriban, contributed articles to newspapers, newspaper articles in the society section, magazine articles, and op-eds. The online cafe forum is called "Little Yongsan Duriban" (Note 7) and is hosted on the search engine Daum. Newspapers searched include daily papers (Hankyoreh, Kyunghyang Shinmun, Kukmin Ilbo, Hankook Ilbo, Seoul Shinmun, Naeil Shinmun), internet newspapers (Oh My News, Pressian), weekly news magazine (Hankyoreh 21, Weekly Hankook, Sisa Korea, Media Us, Media Today), and internet media (Redian, Prometheus, Left 21, Yonhap News).

For the in-depth interviews, we used purposive sampling and identified persons who were participating in the arts and cultural activities of the Duriban community and used snowball sampling. The purpose and intended use of information collected, interview content, and confidentiality agreements were explained in detail to every participant. Interviews started with naive open ended questions about the event and allowed the interviewee to provide his or her own commentary and gradually extended questions based on their answers. The interview followed a semi structured questionnaire and under the consent of participants the interviews were recorded from start to finish. These audio files were transcribed by the interviewer within 24 hours of completing the interview and also accompanied by field notes in order to produce an accurate record of the interview as much as possible. These transcriptions were then repeatedly read through to identify key concepts and domains. Interviews were terminated at the point of theoretical saturation when researchers no longer found new concepts.

Culture and arts activities in Duriban continued for 14 months from February 2010 to June 2011. Researchers chose participants who had been involved in these activities for at least half of the entire period (e.g. seven months) and conducted one to two in-depth interviews. During the data analysis after the first interview, when considered necessary, we contacted the participants for a second interview, either via face-to-face or telephone. These participants who had minimum seven months of experience or "community transfers" (Note 8) were also asked to identify other "community transfers" who were included in the sample through snowball sampling. Our final sample of five persons constructed in this manner consisted of those with a minimum eight months experience to the full period of fourteen months. Table 2 is a summary of participant information. 
Table 2. Descriptive information of interview participants

\begin{tabular}{|c|c|c|c|c|c|c|c|}
\hline Participant & Gender & Age & $\begin{array}{l}\text { Duriban } \\
\text { activities } \\
\text { experience }\end{array}$ & & Introduction to Duriban & $\begin{array}{l}\text { Experience in arts } \\
\text { and cultural } \\
\text { performance }\end{array}$ & Occupation \\
\hline A & Male & 44 & 8 months & & $\begin{array}{l}\text { Belong to the same artist } \\
\text { association of one of the } \\
\text { key actors of Duriban } \\
\text { community formation }\end{array}$ & 19 years & Poet \\
\hline B & Female & 31 & 8 months & & $\begin{array}{l}\text { Recommended by } \\
\text { colleague }\end{array}$ & 2 years & Poet and editor \\
\hline $\mathrm{C}$ & Male & 42 & 8 months & & $\begin{array}{l}\text { Recommended by } \\
\text { colleague }\end{array}$ & 18 years & $\begin{array}{l}\text { Poet and instructor } \\
\text { (culture and arts } \\
\text { management) }\end{array}$ \\
\hline $\mathrm{D}$ & Female & 40 & 8 months & & $\begin{array}{l}\text { Recommended by } \\
\text { colleague }\end{array}$ & 4 years & $\begin{array}{l}\text { Poet and } \\
\text { homemaker }\end{array}$ \\
\hline $\mathrm{E}$ & Male & 52 & $\begin{array}{l}2 \text { years } \\
\text { months }\end{array}$ & & $\begin{array}{l}\text { Key actor of Duriban } \\
\text { community formation }\end{array}$ & 23 years & $\begin{array}{l}\text { Writer (formerly an } \\
\text { editor at publishing } \\
\text { company) }\end{array}$ \\
\hline
\end{tabular}

This study has defined its unit of analysis as a single case (Miles \& Huberman, 1984) and interviewed the participants of this case. We collected preliminary information on the case through documentary analysis and media data. The purpose of this case study is not generalization but to understand the internal processes of this unique case. Findings from this study will provide useful insights for understanding similar cases (Stake, 2005).

These transcripts were then repeatedly read through to identify key concepts through open coding. These concepts were then reorganized by theme into subcategories, which were finally recoded to categories. The open code was constructed from specific items to general themes and as per the recommendation of Creswell (2006) the analysis results were cross checked between researchers at every step, and subjected to a peer review for a total of twelve rounds. The results followed the repeated comparative method developed by Strauss and Corbin (1990). Interviews were terminated at the point of theoretical saturation when researchers no longer found new concepts.

\section{Results}

\subsection{Document Analysis}

Analysis results of 135 documents collected from an internet forum and articles are as follows. Contents were divided into three broad categories: concept related, arts and culture related, and place related. Among the concept related words, words that described the Duriban situation such as demolition, struggle, or combat were mentioned frequently. Also, words that described people's perception or assessment of the situation such as heart, participation, support, negotiation, hope, and coalition were also frequently mentioned. An interesting point is the high frequency of positive words such as party and festival, which indicates that although Duriban was a site of protest and struggle, it was also one of joy and celebration.

The frequency of arts and culture related words is quite high with a total frequency of 1939 divided over fifteen words. In comparison, concept related words also showed up with high frequency of 2133 times but there were also twenty seven words in this category. The high frequency of arts and culture related words adds support for the implication discussed above that Duriban was a site of enjoyment and celebration through arts and cultural activities.

For place related words, the frequency of Yongsan was highest as many people viewed this case as being very similar to the Yongsan demolition case. Other high frequency words were stage and venue, again indicating that the perception of Duriban as a place of arts and culture was quite prevalent. These results are summarized in Table 3. 
Table 3. Results of document analysis

\begin{tabular}{|c|c|c|c|c|c|c|c|}
\hline \multicolumn{4}{|c|}{ Concept related words } & \multirow{2}{*}{\multicolumn{2}{|c|}{$\begin{array}{lll}\begin{array}{l}\text { Arts \& culture } \\
\text { words }\end{array} & \text { related } \\
\text { Music } & & 497\end{array}$}} & \multicolumn{2}{|c|}{ Place related words } \\
\hline Demolition & 615 & Forum & 27 & & & Yongsan & 318 \\
\hline Society & 268 & Understanding & 17 & Show & 323 & Hongdae & 282 \\
\hline Struggle/combat & 260 & Communicate & 17 & Culture & 195 & Local & 182 \\
\hline Solidarity & 170 & Sympathy & 16 & Band & 171 & Space & 165 \\
\hline Capital & 123 & Fun & 16 & Writer & 167 & Stage & 69 \\
\hline Party & 101 & Change & 13 & Arts & 118 & Venue & 32 \\
\hline Festival & 90 & Play & 10 & Musician & 116 & $\begin{array}{l}\text { Local } \\
\text { community }\end{array}$ & 4 \\
\hline Heart & 68 & Education & 9 & Movie & 90 & Sungmisan & 2 \\
\hline Participation & 60 & $\begin{array}{l}\text { Neighborhood } \\
\text { meeting }\end{array}$ & 5 & Literature & 80 & & \\
\hline Support & 54 & Enjoyment & 4 & Indie band & 69 & & \\
\hline Negotiation & 51 & Intermediary & 2 & Audience & 62 & & \\
\hline Hope & 46 & Learning & 1 & Singer & 22 & & \\
\hline Coalition & 35 & & & Theatrical play & 16 & & \\
\hline Tragedy & 28 & & & Visual arts & 11 & & \\
\hline Conversation & 27 & & & Poetry reading & 2 & & \\
\hline TOTAL & 2133 & & & TOTAL & 1939 & TOTAL & 1054 \\
\hline
\end{tabular}

\subsection{Interview Analysis}

This study focused on Duriban as a case of successful conflict resolution during a local development process. Interviews searched for the elements of this success. Through constant comparison of data, eighty two concepts were extracted. These concepts were grouped into eighteen subcategories that were finally grouped into eight categories. Table 4 shows these concepts, subcategories, and categories.

The major findings can be summarized as below. Participants pointed out that they were motivated to participate in Duriban's protest to offer emotional support, out of sympathy for hardship, and because of the loose networks of bonds created among each other. The arts and cultural activities served as an impetus for continued action and volunteerism, encouraged interaction and bonding, and stimulated wide participation. The Duriban activities can be seen as a form of community building which gave new meaning to the space, transforming a physical space into a psychological one. 
Table 4. Results of interview data analysis

\begin{tabular}{|c|c|c|}
\hline Concept & Subcategory & Category \\
\hline $\begin{array}{l}\text { Want to help with my writing, give support } \\
\text { with my songs, share our films, kalguksu } \\
\text { concert }\end{array}$ & $\begin{array}{l}\text { Offer help or support through } \\
\text { activities that one enjoys }\end{array}$ & \\
\hline $\begin{array}{l}\text { Gives opportunity to gladly create a united } \\
\text { front, young people united, move forward } \\
\text { together, participate if schedule permits }\end{array}$ & $\begin{array}{l}\text { Opportunity to participate, bond, } \\
\text { mobilize }\end{array}$ & Emotional support \\
\hline $\begin{array}{l}\text { Fun to hang out together, enjoy each other's } \\
\text { company, everyone have fun }\end{array}$ & Share joy & \\
\hline $\begin{array}{l}\text { Kicked out of an indie band venue, lost our } \\
\text { space because we could not afford the rising } \\
\text { rent, losing ground where we can perform }\end{array}$ & $\begin{array}{l}\text { Sympathy based on similar } \\
\text { situation }\end{array}$ & \\
\hline $\begin{array}{l}\text { Our interests aligned, needed a venue for } \\
\text { indie band performance, made up of actual } \\
\text { work by writers, opportunity to introduce } \\
\text { my piece, naturally influences my work, a } \\
\text { stage that lets you do something you are } \\
\text { good at }\end{array}$ & Mutual help/win-win activities & $\begin{array}{l}\text { Bonds of sympathy/ } \\
\text { fraternity }\end{array}$ \\
\hline $\begin{array}{l}\text { Easy to participate without any pressure, } \\
\text { feels comfortable, free to enjoy with } \\
\text { passion, relaxed without formalities, loose } \\
\text { network of relationships, equal and free, } \\
\text { allows people to just hang out }\end{array}$ & Lack of restriction or confinement & Loose network or bonds \\
\hline
\end{tabular}

Willing to participate any time, participate by writing poems, participate voluntarily, friendly atmosphere and development of intimacy encourages participation, can inform people about the situation through writing, participants do what they want, started naturally

Fresh and fun, fun to do something, just fun without any thoughts, lively and fun, just us enjoying and having a good time,

Sustained repeat participants and new participants, thought of performing again, all kinds of people come again and again to hang out and participate

Opportunity to meet the bands and writers I have been a fan of, felt closer to the audience, perform for the audience, a space to enjoy freely, perform and have events freely

Artists and audience meet

Interaction and bonding Voluntary participation

Fun activity
Impetus for continued action and volunteerism
Self-motivated, repeated participation

Created common ground and interest, similar people gathering, tears at the last concert, connected on an emotional level, shared emotions with people 
Became interested after coming to Duriban, shocking documentary, completely different experience, meet new people

Has value of meeting all kinds of people, draw interest in Duriban's forced eviction, just coming here makes a difference, diverse members

Change the meaning of space, place to perform, multistage, autonomous use of space, lament that such a great place will disappear

First squat in this country, artists occupy the space, do not think of it as a place of combat, countervailing the symbol of battlefield through literary activities, so much joy enough to forget the struggle and conflict

Unique location where artists gather, effect of Hongdae location, geographic location of Hongdae in Seoul, possible because located in Mapo gu

Meaning of a person occupying this space, focus on the space not the performer, an equal space where we are not focused on one person, community transfer

Participation of local independent artists, physical place having symbolic meaning, unfamiliar but acting as a midpoint, a symbolic victory for forcefully evicted tenants
New experience

Encourage and motivate wide participation

Raise awareness

Activities changing the meaning of space

Transformation from physical space to a psychological space

Changing the definition of space

\section{Uniqueness of location}

\author{
Autonomous space Creating a meaningful \\ and symbolic space
}

Middle ground between art and purpose

\subsubsection{Motivation for Participation}

All community transfers described how their participation in Duriban activities had led them to a shared victory and success rather than saying that they had personally contributed something and felt a sense of individual accomplishment. They identified the following three factors as motivation for participation: 1 . to provide emotional support 2. a sense of fraternity or bonds of sympathy 3. lack of rigid structures and presence of freedom based on loose networks.

Participants emphasized the desire to offer support through whatever talents they could offer. In particular, it allowed people who had felt sympathy for the Duriban situation to do something and express their feelings. Whether it was writing poems, writing stories, singing songs, or simply bringing drawings or photographs and sharing it with others, watching a movie together, all of these activities were combined to create the Kalguksu Concerts.

Participants often spoke of feeling a sense of sympathy and brotherhood because they had suffered in the same way before. They said they wanted to help, because they understood. In fact, the indie bands that had about 2 000 to 3000 audiences at every concert were able to sympathize immediately with Duriban protestors because they had been forced to leave their practice rooms and stage venues since they were no longer able to pay the expensive rent in the Hongdae area. The participation of these indie bands was more than simply doing something together. The indie bands benefited from these activities as well. Duriban served as a place where indie bands from various areas came together, shared their concerns and difficulties, and became the stage where they attempted to create a coalition of indie bands so that they could be independent and protect each other.

The loosely knit networks had a significant role in the Duriban community participation. In other words, the organization and management of the Duriban activities did not follow a set of rules or regulations but rather was 
flexible and always open to discussion or negotiation through the Ban Sang Hwe [neighborhood meetings]. (Note 9) This is quite interesting since participants did not gather together with a set agenda or plans to continue these activities for an extended period of time. However, the loose, casual, and easy-going relationships ended up doing just that: activities that took place repeatedly in a voluntary manner. A key factor seems to be that participants were not coming together to fill up a set time or schedule, but rather because they were able to come whenever and share whatever they felt moved to share. The fact that there were no rules or regulations in this space signifies utmost respect for the freedom of expression of these artists.

The activities at Duriban gave a sense of comfort and moreover, a sense of freedom. The activities were not artificially seeking fun but rather these people were simply doing what they enjoyed and the fun and joy came naturally. The fun also came from the sharing of these activities or moments of joy. The presence of joy when people come together can act as a propelling force to push a community towards a more positive direction.

The culture and arts at Duriban was not about making a star out of one performer or one group. The focus of these activities was on the situation that Duriban was in. Therefore, the focus was not on one person but rather on everyone participating at Duriban. Every participant and audience member was considered equal in this manner

\subsubsection{The Role of Culture and Art}

The arts and cultural activities served as an impetus for continued action and volunteerism, encouraged interaction and bonding, and stimulated wide participation. Arts and cultural activities, in their most genuine definition, cannot be forced. These activities are also sources of joy and enjoyment that people choose to engage in voluntarily. The fact that Duriban's protest was centered around these activities meant that continued participation in the form of volunteerism could be sustained.

Protestors did not have to make a conscious effort to explain Duriban's situation and argue for its position, but rather people who came to participate or observe the arts and cultural activities naturally learned these things through the atmosphere and this led to conversations on Duriban's situation, which ultimately led to building a common ground and understanding.

Even the concerts or poetry readings were not one-sided in the sense that fans were able to meet their favorite artist, but rather they were interactive in that artists were able to meet people who liked his or her music, poems, or writings. The meetings served as an arena where artists and fans could meet and communicate with each other about their shared interest and love for art.

People who came to Duriban out of their love and interest in music and literature began to take an interest in Duriban's struggle. The wide variety of arts and cultural activities meant that almost anyone could participate and these activities served as a path of new experience for these participants. It created the opportunity for fans or guests to learn about what these musicians or artists were interested in or concerned about.

\subsubsection{The Importance of Space and Place}

The Duriban activities can be seen as a form of community building which gave new meaning to the space, transforming a physical space into a psychological one. The meaning of struggle in Duriban did not mean a battle or conflict but rather many people coming together with a shared purpose and making a statement. Research participants themselves were aware of the role that arts performances had played to act as a countervailing force to a site of struggle and conflict because everyone was enjoying themselves and having fun.

Duriban was a place where artists and audience members could come together and enjoy music and literature and as the participants called it, 'a party.' This sense of joy and celebration seemed to have been shared by those who were not aware of this space as a protest site as well as those who were, and this positive atmosphere is what attracted people to the space and ultimately transformed the meaning of this place. Duriban was considered a place of interaction and communication, rather than an uncomfortable and difficult place.

The space that Duriban was situated in and its symbolic meaning emerged as an important concept. In particular, Duriban was close to the Hongdae area where Korean indie bands are active. This image of Hongdae as a place of art, youth, and vitality affected the image of Duriban as well.

Moreover, the Mapo district that Duriban and the Hongdae area are both located had a significant effect on the narrative of Duriban as a space with meaning. In detail, the Hongdae area was also well-known for its residents who are poets and writers and these residents were always there as a potential source of emotional support. Also, the Sungmisan community, which was widely publicized as a voluntary community created by people trying to collectively solve local issues is also located in the Mapo district and therefore a sense of collective action and 
comradeship may have already existed.

\section{From Urban Conflict to Urban Progress}

This paper has examined the Duriban case of urban redevelopment conflict in Seoul, Korea through documentary analysis and in-depth interviews. We found that the culture and arts activities at Duriban encouraged community building and led to the peaceful resolution of this urban conflict. We conclude this paper by summarizing some interesting characteristics of this case and their implications.

First, the culture and art activities at Duriban can be viewed as a long series of parties in that they were not like the structured performances or activities that are organized by universities or public organizations. These activities were not coordinated by professionals but rather by voluntary performers who wanted to share their work. Moreover, these performances were centered around a loose distinction between performers and audiences such that they looked more like a group of people simply enjoying each others' company rather than a performance.

Second, Duriban's culture and art activities went beyond simple performances and actually transformed its venue. Urban spaces are usually considered to belong to an owner who acquires the space through capital and therefore dictates the use and purpose of that space. Duriban gives reason to reevaluate this formula as it was the people who were physically present in the space but without any legal claims to it that dictated the use, purpose, and even created meaning of that space.

The implications from the Duriban case for community building is as follows. First, the Duriban community structure was decentralized, non-hierarchical or horizontal, and informal. These characteristics seem to challenge the cultural typology of Korea as defined by Hofstede (2001). For example, according to the Hofstede Index Korea is identified as a hierarchical, collectivist, and uncertainty avoiding country. However, in the Duriban case we saw a community that emphasized the equal status of everyone, respected each individual's right to act on his or her own will, and did not have formalized rules. Barrios (2010) pointed out that once a local community is formed on the basis of shared value or locality, then the next step includes a stage of conflict in which members are forced to find a solution for how to combine and reconcile their differences. However, this natural stage of conflict did not exist in the Duriban case. A credible explanation is that there were no leaders or decision making body that dictated people's actions but rather there was a sense of trust and silent understanding of mutual support. In this process, the Duriban neighborhood meetings played an important role in that this was the forum through which every single decision was made from negotiations with the contractors to the mundane items such as the use and cleaning of toilets in the building. These neighborhood meetings took place every week and was open to anyone and everyone.

Second, community building through culture and art can lead to group empowerment, enhance a sense of community for the larger society by bringing in ordinary citizens, and ultimately strengthen political power when combined with squatting or sit-in protests. The culture and arts activities created a middle ground where people from diverse backgrounds could connect with each other, and the element of joy and fun made it easy to extend this circle of connection to ordinary citizens. This meant that the Duriban case was able to extend its circle of support to the larger Korean society and as mentioned in the interviews this was one of the reasons why developers found it impossible to forcefully evict these tenants. Culture and arts have been discussed in connection to urban development and urban policies in the past. For example, Strom (2002) used the New Jersey Performing Arts Center in Newark as an example of using arts as a way for urban revitalization with public officials, arts entrepreneurs, and arts patrons as cooperatively working together. In Britain, John Myerscough (1988) argued that the arts sector can make a positive economic contribution to deal with the problems of industrial decline and ultimately contribute to urban regeneration, and again the Arts Council of UK published a report called 'Partnership: Making Arts Money Work Harder' to emphasize how arts contribute to urban renewal (as cited in Belfiore, 2002). Sharp, Pollock, and Paddison (2005) explained that pubic art can be used for social inclusion during urban regeneration projects. However, as far as we know this is the first case in Korea wherein culture and art activities were not merely used as tools to further a redevelopment agenda but rather transformed the agenda itself, especially by voluntary non-governmental actors.

In conclusion, the Duriban community was born out of a place of struggle through the occupation of artists and grew into a community of joy and celebration. Local communities are generally distinguished into associative community or community of action. Duriban is both a community of purpose and community of action, and future studies should explore how arts and culture can be incorporated into a model of urban development and community building. 


\section{Acknowledgement}

This work was supported by the National Research Foundation of Korea Grant funded by the Korean Government (NRF-2013S1A3A2054622).

\section{References}

Barrios, C. (2010). The People in Charge: Civil Society and State Building in the Democratic Republic of Congo. Retrieved March 15, 2013, from http://www2.lse.ac.uk/IDEAS/publications/ideasToday/02_Congo.pdf

Belfiore, E. (2002). Art as a means of alleviating social exclusion: Does it really work? A critique of instrumental cultural policies and social impact studies in the UK. International Journal of Cultural Policy, 8, 91-106. http://dx.doi.org/10.1080/102866302900324658

Byun, C. H. (2011). The Failure of New Town Project and Crucial Tasks. People and Policies, 2, 80-91.

Cho, M. R. (2010). Appraisal of New Town Development in Seoul and Seeking its Alternatives. Real Estate Studies, 17, 47-65.

Choi, B. D. (2001). Urban Redevelopment and Real Estate Investment. Journal of social science research, 9, 491-509.

Corbin, J., \& Strauss, A. (1990). Basics of qualitative research: Grounded Theory procedures and techniques (2nd ed.). Thousand Oaks, CA: Sage Publication.

Creswell, J.W. (2008). Research design: Qualitative, quantitative, and mixed methods approaches (3rd ed.). Thousand Oaks, CA: Sage Publication.

Dobbs, S. (2002). Urban Redevelopment and the Forced Eviction of Lighters from the Singapore River. Singapore Journal of Tropical Geography, 23, 288-310. http://dx.doi.org/10.1111/1467-9493.00132

Doshi, S. (2012). The Politics of the Evicted: Redevelopment, Subjectivity, and Difference in Mumbai's Slum Frontier. Antipode, 45(4), 844-865. http://dx.doi.org/10.1111/j.1467-8330.2012.01023.x

Dowall, D. E. (1994). Urban Residential Redevelopment in the People's Republic of China. Urban Studies, 31, 1497-1516. http://dx.doi.org/10.1080/00420989420081391

Fainstein, N., \& Fainstein, S. (2012). The Changing Character of Urban Redevelopment. In R. Weber, \& R. Crane (Eds.), The Oxford Handbook of Urban Planning (pp. 587-608). New York, NY: Oxford University Press.

Greene, S. J. (2003). Staged cities: mega-events, slum clearance, and global capital. Yale Human Rights \& Development Law Journal, 6(1), 161-187.

Ha, S.-K. (2004). Housing renewal and neighborhood change as a gentrification process in Seoul. Cities, 21(5), 381-389. http://dx.doi.org/10.1016/j.cities.2004.07.005

He, S., \& Wu, F. (2009). China's Emerging Neoliberal Urbanism: Perspectives from Urban Redevelopment. Antipode, 41(2), 282-304. http://dx.doi.org/10.1111/j.1467-8330.2009.00673.x

Hofstede, G. (2001). Culture's Consequences: Comparing Values, Behaviors, Institutions, and Organizations across Nations. Thousand Oaks, CA: Sage Publications.

Hong, S. J. (2010). A Study on the Improvements and Analysis on Ongoing State of Prototype New Town Project in Seoul. Real Estate Studies, 42, 37-55.

Kim, N. G. (2009). Civil Organizations' 10 Requests for the Improvement of the New Town Redevelopment Project and Human Rights Concerns of Forced Eviction. Essays in Celebration, 1, 360-373.

Kim, N. G. (2010). The Legal Issue Research about an Expense Allotment Burden on Redevelopment and Reconstruction Undertaking. Real Estate Studies, 17, 191-236.

Kim, S. H., \& Jung, S. (2011). Stop the Redevelopment New Town Project. Space and Environment, 35, 296-318.

Lee, C. M., Bae, Y. J., \& Choi, H. D. (2011). Rental Price Effect of Residential Redevelopment Projects on Non-apartment Housing. Housing Studies Review, 19, 5-24.

Lee, C.-M., Lee, J.-H., \& Yim, C.-H. (2003). A Revenue-sharing Model of Residential Redevelopment Projects: The Case of the Hapdong Redevelopment Scheme in Seoul, Korea. Urban Studies, 40(11), 2223-2237. http://dx.doi.org/10.1080/0042098032000123268

Lee, E. G. (2010). A Study on the Consolidation of the Legal Status of Commercial Tenants in the Downtown 
Remodeling Area. Real Estate Law Studies, 17, 141-165.

Lee, I. S. (2011). A Case Study on the Housing Reconstruction/Redevelopment Project. Kangwon Law Review, $33,143-186$.

Lee, J. K. (2008). A Study on Acquisition Taxation of Housing Redevelopment and Reconstruction. Public Law, 37, 359-387.

Lee, J. S. (2011). Study on Legal Issues and Improvement Measure Concerning City Redevelopment Project. Public Land Law Review, 55, 1-33.

Moon, B. H. (2009). Problems of Redevelopment Policy Laws and Solutions. Public Law, 38, 493-521.

Myerscough, J. (1988). The Economic Importance of the Arts in Britain. UK: Policy Studies Institute.

Ng, M. K. (2002). Property-led urban renewal in Hong Kong: any place for the community? Sustainable Development, 10(3), 140-146. http://dx.doi.org/10.1002/sd.189

Oh, J. G. (2006). Legal Problems in Seoul New Town Development. Public Land Law Studies, 30, 27-46.

Oh, J. J. (2012). A Critical Study on the Decisions of Constitutional Court about Redevelopment: the assumption of public interest vs. the rights for stable residence. Legal Studies, 53, 291-311.

Rahman, M. M. (2001). Bastee eviction and housing rights: a case of Dhaka, Bangladesh. Habitat International, 25(1), 49-67. http://dx.doi.org/10.1016/S0197-3975(00)00026-6

Sharp, J., Pollock, V., \& Paddison, R. (2005). Just Art for a Just City: Public Art and Social Inclusion in Urban Regeneration. Urban Studies, 42, 1001-1023. http://dx.doi.org/10.1080/00420980500106963

Smart, A. (2002). Agents of Eviction: The Squatter Control and Clearance Division of Hong Kong's Housing Department. Singapore Journal of Tropical Geography, 23(3), 333-347. http://dx.doi.org/10.1111/1467-9493.00134

Sorensen, A., Okata, J., \& Fujii, S. (2010). Urban renaissance as intensification: Building regulation and the rescaling of place governance in Tokyo's high-rise manshon boom. Urban Studies, 47(3), 556-583. http://dx.doi.org/10.1177/0042098009349775

Stake, R. E. (2006). Multiple case study analysis. New York, NY: Guilford Press.

Strom, E. (1999). Let's Put On a Show! Performing Arts and Urban Revitalization in Newark, New Jersey. Journal of Urban Affairs, 21(4), 423-435. http://dx.doi.org/10.1111/0735-2166.00029

Waley, P. (2007). Tokyo-as-world-city: reassessing the role of capital and the state in urban restructuring. Urban Studies, 44(8), 1465-1490. http://dx.doi.org/10.1080/00420980701373511

Wu, F., Xu, J., \&Yeh, A. G. (2007). Urban development in post-reform China: state, market, and space. London and New York: Routledge.

Yang, H. S. (2011). A Study on the New Town Development Program: comparing Seoul and Bucheon New Town Project. Journal of Government and Policy, 3, 133-180.

Yang, Y.-R., \& Chang, C.-H. (2007). An urban regeneration regime in China: A case study of urban redevelopment in Shanghai's Taipingqiao area. Urban Studies, 44(9), 1809-1826. http://dx.doi.org/10.1080/00420980701507787

Yeo, G. S. (2010). A Study on the Rescue Plan of the Existing Dweller and the Role of the Public in Urban Redevelopment. Real Estate Studies, 17, 67-88.

Yin, R. K. (2009). Case study research: Design and methods (4th ed.). Thousand Oaks, CA: Sage Publications.

Zhang, L. (2004). Forced from home: Property rights, civic activism, and the politics of relocation in China. Urban Anthropology and Studies of Cultural Systems and World Economic Development, 33, 247-281.

Zhu, J. (2002). Urban Development under Ambiguous Property Rights: A Case of China's Transition Economy. International Journal of Urban and Regional Research, 26(1), 16-57. http://dx.doi.org/10.1111/1468-2427.00362

\section{Notes}

Note 1. This paper uses several Korean terms. Proper terms have been transliterated with the meaning of these words included in square brackets '[ ].' All interview contents have been translated with a focus on delivering the 
overall meaning of the dialogue accurately, rather than a direct word-by-word translation. An English version of select interview excerpts are available in Appendix A.

Note 2. In April 2006 the government designated District 4 of Yongsan as a redevelopment area and designated three private companies to carry out the redevelopment process. The demolition process began in November 2008 and tenants were ordered to move out. The evicted residents who found their livelihoods threatened without alternatives, began a sit-in protest on 19 January 2009. On 20 January 2009, a fire broke out during a clash between the police and protestors leading to casualties. Afterwards the Public Prosecutor's office indicted twenty of the protestors on charges of illegal occupation and five people were imprisoned. The redevelopment plans in this area came to a stall due to disagreements on the development costs and as of March 2013 the site is being used as a commercial parking lot. On 12 March 2013 Yongsan Development Co., the developer of the Yongsan redevelopment project, declared default after failing to pay back a 5.9 billion Korean Won debt (approximately 5.3 million USD).

Note 3. Even the popular terms to refer to these cases are different. The Yongsan case is often referred to as the Yongsan tragedy while the Duriban case is often referred to as the Duriban story.

Note 4. The issue of inequality within Seoul has been persistent and the discussion is often framed around the binary division between the Gangnam area and Gangbuk area. Gangnam literally means the south of the river while Gangbuk means the north of the river. The river referred to here is the Han River which runs across Seoul. The disparity between these two areas have been criticized for many decades as much of the wealth is concentrated on the south side of the river.

Note 5. Kalguksu is a hand-made noodle dish served in hot broth and Bossam is a steamed pork dish served with kimchi and other vegetables.

Note 6. A key data collection method in case studies is participatory observation. However, this study did not utilize this method for the following reason. Our research team had initially planned to employ a case study methodology on 27 May 2011. At the time, all activities at Duriban were being held as before, usually every week. Therefore, we planned to conduct participatory observations for three months from 1 July 2011 to 30 September 2011. However, on 8 June 2011, with a dramatic turn of events, the key actors were able to reach an agreement. Duriban owners agreed to evacuate the building and consequently all activities were cancelled until 30 June 2011. Therefore, the researchers decided to cancel the participatory observations and focused on documentary analysis and in-depth interviews.

Note 7. URL: http://cafe.daum.net/duriban

Note 8 . The term "community transfers" was first used by participant "D" to describe Duriban community members who first arrived as individuals but became members of that community through continued participation and involvement. As this is a term used by someone who is most familiar with the case, we have used this term directly in our paper.

Note 9. Ban Sang Hwe is a general term in Korean society that refers to a neighborhood meeting. These meetings have been traditionally held regularly (e.g. once a month) and consists of one person from each household being present. Issues discussed include anything that has to do with the local community or any neighborhood issues. Traditionally this role has been fulfilled by the female head of household.

\section{Appendix}

\section{Key Interview Excerpts}

Each interview excerpt is followed by the interviewee code and key concept in parenthesis.

1. I guess you could call it the tools that each of us has. Whether it be words or music, the fact that we came together with these and connected with each other, that in itself is meaningful. The fact that we started that, that we put down this footstone, the space that is Duriban. I feel that that is leading to other footstones being placed and these connections are spreading to other areas. And maybe that these waves that are spreading out, maybe that is the meaning and purpose of making this Duriban community.... People who are just doing art in those communities that aren't political, there are a lot of those people out there who are really interested in getting involved. (A; Participation in various ways)

2. Anyways the indie bands saw that (a contributed article in a newspaper titled, 'Water in the desert: Duriban') and they came here. They said they wanted to come right away after they saw that article in February but wasn't able to. They said we want to help but all we know how to do is sing. (E; participate in whatever form you are 
capable of)

3. With the rising real estate prices in Hongdae, the small clubs closed down, and those musicians that were not mainstream, but have a really unique color, they had nowhere to go. These people are the people that came to Duriban. 000 came to Duriban and said our situation, it's not that different from your situation. That's really important. We're not here for moral reasons or out of any moral obligation. We are here because we are the same. (C; participation from sympathy)

4. The people who were in bands performed a lot there. Especially at Duriban, there were a lot of indie bands everyday just performing and these people came together and decided to make this organization to really stand up on their own. They're trying to find a way to make it, to live. These people don't really have a stage, don't have a lot of ways to make money, so they came together to find a way to make a living on their own, I think. That's the motivation I feel they have and they were really the key root and source of energy. (B; Duriban interaction creating opportunities for new community formations)

5. There were about seven or eight people [participating at each poetry reading session] but really I don't think there were people singing or dancing at the beginning. Anyways, there was a writer that brought a gayageum, no it was a geomungo! (Note 1) yes, there was a writer that brought a geomungo and strummed that [after the poetry reading], after reading the piece because we said just do something so someone brought a collection of drawings and we all passed that around, someone brought a picture book and showed that, and read it out loud like that. I think that was really fun. (C; freedom and autonomy without restrictions)

6. I always thought of myself as being more progressive, politically, than these young guys but I realized I have been really conservative, culturally. A lot of things were like that. But as we spent time together we really came together, maybe it was because we really missed each other but we even formed a band with the task force committee members and we performed a couple times already. (Note 2) We did some at Duriban here but also was invited to perform at the cultural festival of the Korean Confederation of Trade Unions and performed in front of Bosingak, and in front of the National Assembly Building for the new progressive party unity event and such...... . (Note 3) I'm a drummer. Doing things like that, just doing things together and dancing, that was really fun. (E; fun activities)

7. Duriban began to receive attention because of these performances...... . Honestly, who wants to go to a strange battleground by himself and nobody knows me and I just go sit in a corner quietly and leave, who wants to come again? Nobody, nobody wants to come back to that kind of place. You feel shy and awkward so it's actually easier to just go to a candle light vigil like in Gwanghwamun intersection and you can participate anonymously. (Note 4) That's the way everyone is and so it's ok but it's really difficult to go to a sit-in site and sit there on your own. But this place made it really easy and comfortable to do that. Things like performances made you come to Duriban naturally! That's what it did and also publicized Duriban and it was just so important!....... Usually, it's the same people who come once, come twice, and come three times. But here, there were always new people. It was mixed. (E; Performances brought diverse people together)

8. People are suffering there right? So it wasn't so much helping them but I just went there thinking maybe I can do something, anything and we did a poetry reading and we just felt like we really enjoyed ourselves............ Nobody knew even until then that Duriban would be resolved like that. I thought wow this is helping in some way and I made all these connections with people there. (D; Transformed a place of struggle into an enjoyable place)

9. I think it's rare that people from all different areas come together in one place continuously for such a long time and protest with citizens and bond together.......Yes, yes I think perhaps the idea of being a main actor was what made Duriban move forward dynamically. I mean people who participated once aren't thinking this is a place you participate in once and then just sit there but oh hey I should check out Duriban again. Hey I haven't done a Duriban show in over a month. I should play there once and like that. That's the biggest source of strength. (B; continued participation)

10. If there's a poetry reading people come. Whether people know Duriban or not, they come. After they see Duriban they realize that there are places like this and began to take interest. Or they might not take interest but still they realize that is a demolition site and there is a performance here. People just coming here and enjoying and seeing, just that, makes people think something needs to change here........ There are people that come here because they are interested in Duriban itself and the most interesting thing is young female students are coming here on their own. In fact, if you ask them to come up here and introduce themselves they will say that. They say I am so and so from such and such neighborhood and I came because I'm curious how this Duriban thing works. (C; Meeting through performances and creating common ground) 
11. What these performers are saying is that the level of intimacy with the audience is different. They are right there in front of your eyes and they react in front of your eyes and I feel that too and it's not because the audience is like wow or anything but when I read a poem in a cafe or theatre it really feels like I'm acting. But here, here you're just making eye contact and so it's not because we are talking to the audience but there is that subtle difference........ What I heard is, and this is also mentioned in my writing, but when these guys were meeting they were like if people come then people come if not then not but then 000 said no let's do a poetry reading for an audience and that's how it changed from this internal thing to an external thing. (D; Intimacy with audience)

12. If you look at how Duriban works, art played a big part in that. It made people come, and more people come, and participate, and it made them come again and stay and participate. (C; the role of arts and cultural activities)

13. I think people thought, I hear there is a poetry reading at a place like this and they were curious, like what is this and this poet that I liked when I was a writer I liked the poet 000 but it was difficult to meet him or her unless it's at a book signing but heard they are doing a reading at this place. So these young aspiring writers and literary enthusiasts came to see this poet. So these people come with interest and say I'm here to see the poet so and so or the writer so and so. (B; opportunity to meet)

14. First of all, it's really scary that this is a place that has been ordered for forced demolition. You feel like you need to fight here and struggle here and to lecture that, to give a lecture like that might be really boring but to go to a poetry reading and listen to a poem and listen to music and songs and feel like you're playing I think maybe that's what made the difference (B; transformation of a demolition site to a arts and culture site)

15. What's the use? Let's end it. No we can't. Each and every person is so important and they have been preparing for the event in their own way by writing in newspapers, and writing poems, and practicing so how can we do that to these people how........ That's not right. So we earned another month like that. So after the poetry reading and after anything finished we said our goodbyes and had a small beer party and said hey let's have a proper, big party when Duriban opens again. So that's what we said and after the very last show there was just so much jeong (Note 5) and so we were all just hugging and crying. (E; Sorrow over losing a place of meeting and interaction)

16. There were people that lived there [to participate in the arts and cultural performances]. As soon as everybody left the contractors would come in, intrude that space and take over it so it was really important that somebody was there at all times. (B; the importance of people being in the space to protect it and ultimately lead to the transformation of the meaning of space)

17. (laugh) so anyways these people were really sad that Duriban was no longer there, you know? (Did they used to perform somewhere before?) Probably at a club. Maybe Hongdae but there is no place like Duriban where you can have a meeting and there's a meeting space upstairs and you can sleep on the second floor, have a show on the third floor, and go have a smoke on the fourth floor rooftop, there is just no place like this. After that place disappeared, I mean honestly it is a good thing for 000 or for Duriban it's a great thing so I didn't say this but it did make me sad, in fact. When we realize that the place where we had these poetry readings is gone, it's a little, you know. There will never be a place like that again, probably ever. disappearing)

(D: sadness over Duriban venue

18. [Duriban] is actually squatting. Because people who do not own the house are going in there and protesting for a long time while fighting, but something artistic happened in the midst of that. Our country has never had squatting. We can say that there hasn't been any until now. There have been instances where people have tried to mimic foreign cases and go in there for a few hours and leave or leave with the consent of the owner. ......... In the case of Duriban it was a shopping arcade........ It should have been completely empty but artists occupied that and changed that place and people who came started to develop interest in demolition sit-ins or maybe there are people that have a shared interest in protest but as the performances started people who just loved art showed up. People who love poetry and music came and just stayed. ......... They're not doing anything there, they're just hanging out. And then maybe they'll do some work and help out a little. I asked why they were there and they said because this band that I like or this writer that I like comes here so that's why I'm here and I will continue to be here. And that's why this community thing, of this is where I belong began to happen. (D; First example of squatting in Korea)

19. I'm sure there are a lot of factors, but what's important is that, this is what the owner 000 said, that he is just really grateful that this place is not a battleground because of the literature and that he is thankful for that. That's how the owner thinks. That perhaps that's why the contractors didn't bulldoze this place and I don't know about that. I don't know about that, but that's how he views the situation. (D; cultural performances transforming space) 
20. That was the most important thing. What does the district do for us? See it was possible because this was Mapo. Because it was Mapo there are so many places, I mean a lot less today, but still, there are a lot of these place like Sungmisan community all over this area. (A; the influence of Hongdae and its symbolism)

21. This area, here, in this area there were a lot of independent artists there and these people showed immediate interest ........ we called this the island of Hongdae because really, like an island, this place has all these shopping malls that are really crowded and bustling and then you just walk a couple of steps over here and it's this one shattered building all alone and so to independent artists it's this immediate feeling of fraternity like hey this place is just like us. They're being pushed out and we have been building this space Hongdae as a place of art and then one day that was just taken over by capitalists and we are being kicked out, and that Duriban there, also has that characteristic of housing these local artists and I think maybe that's what the key factor was. (B; participation of local artists)

22. They said let's get together and read some poems with a group of friends and colleagues and then someone just said hey why don't we do a poetry reading and that's how it started. Just naturally. (D; autonomous space)

23. I think that maybe that's why everyone was equal. We can't call it poet so and so's publication party or so and so's poetry reading when we're doing this at Duriban. Yes, that person may be there but it was understood that it was about the support for this fight or interest or some kind of connection in whatever way. The demolition site and author and there was never a focus on just the author, and even if there was it was just for a short instance and the focus would be split so fast and other people, other contexts would come in. That's why the physical space also had a symbolic meaning. ( $\mathrm{D}$; autonomous space)

24. I actually don't know most of the people. I came because I wanted to know what kind of place this Duriban was. That was it and so there was that and also after just listening to them and it's really funny if I think about it now but anyways they could have felt awkward and maybe still a little awkward but I think we found this kind of middle ground. It doesn't give the feeling of a full blown protest but that doesn't mean it's just completely ignoring the social issues so it's right in the middle. I think that's why I came. ........ What these performers are saying is that the level of intimacy with the audience is different. They are right there in front of your eyes and they react in front of your eyes and I feel that too and it's not because the audience is like wow or anything but when I read a poem in a cafe or theatre it really feels like I'm acting. But here, here you're just making eye contact and so it's not because we are talking to the audience but there is that subtle difference. I think that difference comes from the spatial characteristic. I think the first thing is that this is a demolition site and that's why a place like this can be created. There just isn't much difference between the performance space and audience space. If I put this chair like this then it's a seat and we can put the chairs in a circle or I mean we make a performance space just out of convenience but there really isn't much meaning to the stage and house and we just kept trying to include the audience in this way. (C; creating meaning in space)

Notes

Note 1. Gayageum and Geomungo are tradition Korean musical instruments.

Note 2. All performances were cancelled after Duriban negotiations were reached.

Note 3. Bosingak is a large bell pavilion in downtown Seoul. It is a Korean landmark where many important political and cultural events take place. For example, on new year's eve there is a bell ringing ceremony (similar to New York's Times Square) and the bell is rung at midnight on the day before the presidential inauguration to signal the beginning of a new government.

Note 4. Gwanghwamun is the largest gate of the Gyeongbokgung Palace in downtown Seoul. It is another Korean landmark where many ceremonies, festivals, or public protests take place.

Note 5. Jeong is an emotion that is symbolic of Korean culture. This emotion is often translated as attachment, affection, and consideration. See: http://english.visitkorea.or.kr/enu/CU/CU_EN_8_8_1_4.jsp

\section{Copyrights}

Copyright for this article is retained by the author(s), with first publication rights granted to the journal.

This is an open-access article distributed under the terms and conditions of the Creative Commons Attribution license (http://creativecommons.org/licenses/by/3.0/). 